\title{
Molecular detection of Bartonella, Ehrlichia and Mycoplasma in feral dogs of El Pedregal de San Angel Ecological Reserve in Mexico City
}

\author{
Detecção molecular de Bartonella, Ehrlichia e Mycoplasma em cães selvagens \\ da Reserva Ecológica El Pedregal de San Angel, na Cidade do México \\ Pablo Arenas ${ }^{1}$; Guillermo Gil-Alarcón ${ }^{1}$; Sokani Sánchez-Montes ${ }^{2 *}$ (D); Mariana Paola Soto-Trujillo ${ }^{3}$; \\ Edith Fernández-Figueroa ${ }^{2,4}$; Claudia Rangel-Escareño ${ }^{4}$

\begin{abstract}
${ }^{1}$ Reserva Ecológica del Pedregal de San Ángel - REPSA, Secretaría de la Reserva Ecológica del Pedregal de San Ángel, Universidad Nacional Autónoma de México - UNAM, Mexico City, Mexico

${ }^{2}$ Centro de Medicina Tropical, Unidad de Investigación en Medicina Experimental, Facultad de Medicina, Universidad Nacional Autónoma de México - UNAM, Mexico City, Mexico

${ }^{3}$ Facultad de Medicina Veterinaria y Zootecnia, Universidad Nacional Autónoma de México - UNAM, Mexico City, Mexico

${ }^{4}$ Laboratorio de Genómica Computacional, Instituto Nacional de Medicina Genómica, Mexico City, Mexico
\end{abstract}

Received January 17, 2019

Accepted September 11, 2019

\begin{abstract}
Free-ranging and feral dogs represent a group of unattended companion animals. They impact wild animal populations by predating native species, displacing predators and introducing exotic pathogens. The aim of this work was to describe the molecular occurrence of Rickettsia, Ehrlichia, Anaplasma, Mycoplasma and Bartonella in feral dogs. The study was carried out in the last relict of a protected area in Mexico City. Blood clots samples from 19 dogs were obtained and analyzed for detection of specific fragments of the 16S-rRNA gene for Anaplasma, Ehrlichia and Mycoplasma and citrate synthase $(\mathrm{glt} A)$ for Bartonella and Rickettsia. Our results showed that DNA from three bacteria species (Bartonella vinsonii subsp. berkhoffi, Ehrlichia canis and Mycoplasma haemocanis) was present with frequencies ranging from 5.3 to $15.8 \%$. This is the first record of $B$. vinsonii subsp. berkhoffii and $M$. haemocanis in dogs from México, and also the first finding of Ehrlichia canis in Mexico City. It is important to perform surveillance of feral dog populations in order to identify the impact of these pathogens on wild animal populations and Public Health in order to establish prevention and protection programs.
\end{abstract}

Keywords: Canis familiaris, flea-borne pathogens, Mexico, tick-borne pathogens.

\section{Resumo}

Cáes errantes e selvagens representam um grupo de animais de companhia livres. Eles impactam as populaçóes de animais selvagens pela predação de espécies nativas, deslocando predadores e introduzindo patógenos exóticos. O objetivo deste trabalho foi descrever a ocorrência molecular de Rickettsia, Ehrlichia, Anaplasma, Mycoplasma e Bartonella em cães selvagens. O estudo foi realizado no último ecossistema de uma área protegida na Cidade do México. Amostras de coágulos sanguíneos de 19 cães foram obtidas e analisadas para detecção de fragmentos específicos do gene 16S-rRNA para Anaplasma, Ehrlichia e Mycoplasma e citrato sintase (gltA) para Bartonella e Rickettsia. Nossos resultados mostraram que o DNA de três espécies de bactérias (Bartonella vinsonii subsp. berkhoffi, Ehrlichia canis e Mycoplasma haemocanis) estava presente com frequências variando de 5,3 a 15,8\%. Este é o primeiro registro de B. vinsonii subsp. berkhoffi e $M$. haemocanis em cães do México, e também a primeira descrição de Ehrlichia canis na Cidade do México. É importante realizar a vigilância das populaçóes de cães selvagens para identificar o impacto desses patógenos nas populaçóes de animais silvestres e na Saúde Pública, a fim de estabelecer programas de prevenção e proteção.

Palavras-chave: Canis familiaris, patógenos transmitidos por pulgas, México, patógenos transmitidos por carrapatos. 


\section{Introduction}

Invasive mammalian predators, such as feral dogs, are arguably the most damaging group of exotic species for global biodiversity (DOHERTY et al., 2016). They can live in extreme conditions in human-dominated ecosystems, restructuring food webs and endangering native fauna (SUZÁN \& CEBALLOS, 2005). Dogs display a wide range of social organization, from solitary living in human homes to living in packs as free-ranging and feral dogs (PAUL et al., 2014). Free-roaming dogs (those that are not permanently under human control) are thought to account for about $75 \%$ of the global dog population. Dogs requiring no human contact (often described as feral) (HUGHES \& MACDONALD, 2013) have been considered as potential reservoirs for zoonotic pathogens, a significant public health concern worldwide (CRUZ-REYES, 2009; DEPLAZES et al., 2011; CHEN et al., 2012; FANG et al., 2015).

El Pedregal de San Angel Ecological Reserve [REPSA after its Spanish acronym] produced by the Xitle Volcano eruption approximately 1670 years ago, is located inside the Universidad Nacional Autónoma de México [UNAM]. This reserve covers 237.3 ha, and is inhabited by least 1,821 species of different tax, including 130 birds, 20 reptiles and 33 mammals among others (CASTILLO-ARGUERO et al., 2007; ESTAÑOL-TECUATL \& CANO-SANTANA, 2017). Buildings and wide avenues are surrounding this reserve and it has been constantly affected by irregular garbage deposition and invasion of feral fauna, among other problems (MARTÍNEZ-OREA et al., 2012). With respect to the feral fauna, it has been particularly worrisome with the presence of antibody titers in dogs against rabies, Toxoplasma gondii, and parvovirus (SUZÁN \& CEBALLOS, 2005), suggesting an important risk for public and ecosystem health. However, no studies have been conducted to evaluate the presence of tick-borne and flea-borne pathogens in feral dogs, although previous studies have shown the presence of Bartonella henselae in feral dogs from UK using serological techniques (BARNES et al., 2000), and Ehrlichia canis from Costa Rica using serological and molecular techniques (BARRANTES-GONZÁLEZ et al., 2016).

For this reason, the aims of this study were to perform the molecular detection and characterization of five bacterial pathogens (Anaplasma, Bartonella, Ehrlichia, Mycoplasma and Rickettsia) in feral dogs of El Pedregal de San Angel Ecological Reserve in Mexico City.

\section{Materials and Methods}

\section{Study site}

The study was conducted in El Pedregal de San Angel Ecological Reserve [REPSA] in Mexico City (N19 18'31"-19¹9'17”, W99 $\left.10^{\prime} 20^{\prime \prime}-99^{\circ} 11^{\prime} 52^{\prime \prime}\right)$, located in southern Mexico City, within the Universidad Nacional Autónoma de México [UNAM]. This reserve consists of 237.3 ha divided into three core zones and 13 buffer zones (171 ha correspond to the core zones and 66 ha to buffer zones) (Figure 1A) that are under long-term disturbance (fragmentation and isolation) (SUZÁN \& CEBALLOS, 2005). The average annual temperature is $15^{\circ} \mathrm{C}$ and $700-900 \mathrm{~mm}$ of rainfall.
A)

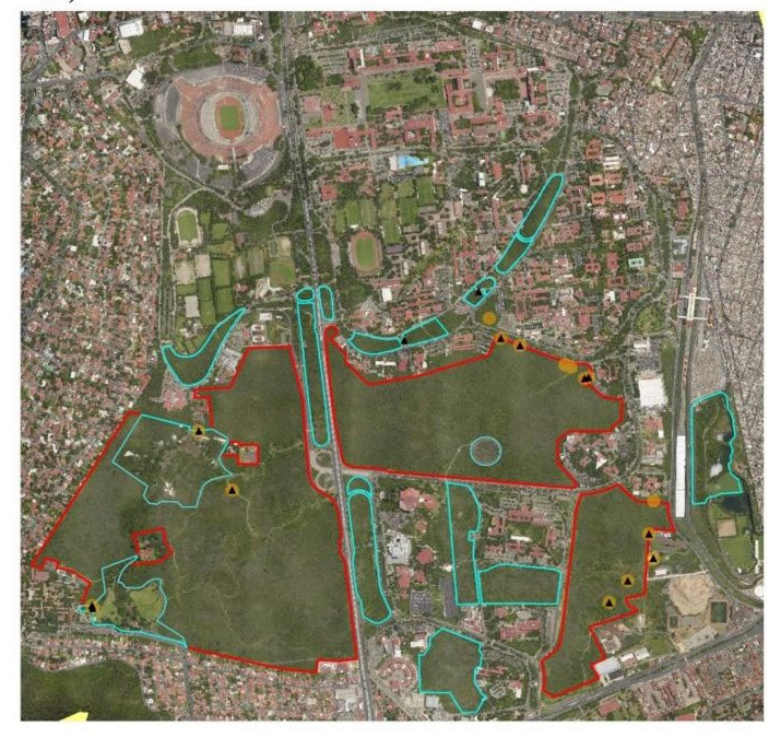

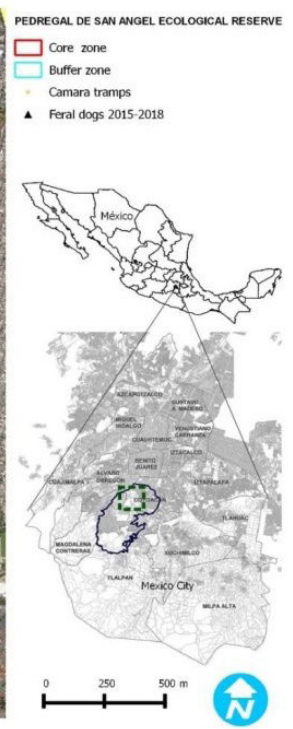

B)

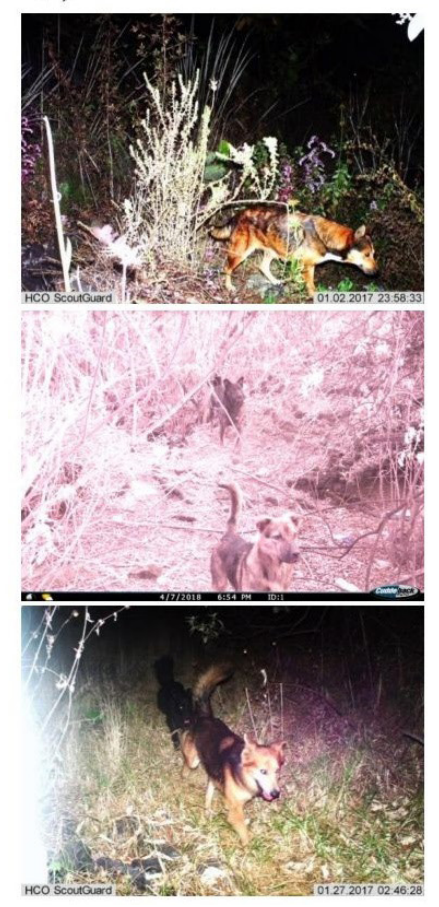

Figure 1. (A) Study area (southern portion of Mexico City) showing the sighting of feral dogs in several parts of El Pedregal de San Angel Ecological Reserve, Mexico; (B) Photographic records of feral dogs in which these animals are observed moving in different parts of El Pedregal de San Angel Ecological Reserve, Mexico. 


\section{Capture of dogs}

The study was carried out in a period of three years, spanning from September 2015 to July 2018. Dogs were captured either inside the reserve or in the UNAM campus. For activity patterns, camera traps (Bushnell Trophy Cam HD) were used. Tomahawk traps (Tomahawk Live Trap Co., Tomahawk, Wisconsin, USA) and collar traps (Collarum, Wildlife Control Supplies, East Granby, GT) baited with meat, chicken or dog food, were activated late in the afternoon between 17:00-19:00 h, and checked every two hours during the night until dawn. Dogs that were not captured with the traps were sedated using a dart gun. A fetch pole was used for restraining dogs prior to sedation. The capture methods used tried to avoid unnecessary stress of the animals. Chemical immobilization was performed with a combination of ketamine hydrochloride $(10 \mathrm{mg} / \mathrm{kg})$ and xylazine/ $\mathrm{HCl}(2 \mathrm{mg} / \mathrm{kg}$ ) (Wildlife Pharmaceutics Mexico SA de CV 04930, Mexico). Every dog captured was subject to a clinical evaluation where the age (juveniles or adults) and sex were also estimated. Age was determined based on tooth wear. Dogs were euthanized with an overdose of sodium pentobarbital (60 mg/kg) (PLUMB, 2011) (Salud y Bienestar Animal, 03310, Mexico) and referred to the invasive species control area of the Faculty of Veterinary-UNAM. The procedures were conducted after approval from Ministry of Environment and Natural Resources [SEMARNAT] permit: SGPA/DGVS/03670/2015 and SGPA/DGVS/005615/18: Authorization for management and control of exotic species (dogs and cats).

\section{Sample collection}

As a part of an ongoing project to identify the exposure of feral dogs to viral agents and Leptospira sp., serum samples of the animals were recovered and were used to screen for the presence of several flea-borne and tick-borne bacteria (MYLONAKIS et al., 2009).

Blood samples were collected after immobilization and sedation by jugular or cephalic venipuncture in $\mathrm{BD}$ Vacutainer blood collection tubes $(10-15 \mathrm{ml})$. Samples were preserved at $4^{\circ} \mathrm{C}$ until needed. The serum was extracted at 3,500 rpm for 15 minutes and the blood clots were recovered and stored frozen at $-20^{\circ} \mathrm{C}$ before testing.

\section{DNA extraction}

Five hundred microliters of a 10\% Cheelex-100 solution and $20 \mu \mathrm{L}$ of proteinase $\mathrm{K}$ were added to each blood clot sample, incubated at $56^{\circ} \mathrm{C}$ in a dry bath for one hour. The temperature was increased to $100^{\circ} \mathrm{C}$ for 10 minutes to make the protein denaturation more efficient. The samples were then centrifuged at 14,000 rpm for $15 \mathrm{~min}$, and the supernatant was collected in new tubes and storage at $-20^{\circ} \mathrm{C}$ until further use (BALLADOS-GONZÁLEZ et al., 2018). The amount (in $\mathrm{ng} / \mu \mathrm{l}$ ) and quality (260/280 ratio) of DNA was measure using a Nanodrop Spectrophotometer (Thermo Scientific $^{\text {TM }}$ NanoDrop $^{\text {TM }}$ 2000/2000c).

\section{Molecular detection}

As an internal control of extraction, we amplified a fragment of 620 of cytochrome oxidase subunit I gene (COI) of the dogs, using primers and conditions of Marsico et al. (2010). For bacterial pathogens detection, we amplified several fragments of the 16S-rRNA and citrate synthase genes using primers and conditions reported previously (Table 1 ). The reaction mixture was done in a final volume of $25 \mu \mathrm{L}$, using $12.5 \mu \mathrm{L}$ of GoTaq ${ }^{\circledR}$ Green Master Mix, $2 \times$ of Promega Corporation (Madison, WI, USA), $2 \mu \mathrm{L}$ of primers $(2 \mu \mathrm{M}, 1 \mu \mathrm{L}$ each), $8.5 \mu \mathrm{L}$ nuclease-free water, and 500 ng DNA $(2 \mu \mathrm{L})$. A negative (a reaction mix with-out DNA template) and positive (Anaplasma ovis [MG733099], Bartonella vinsonii vinsonii [KT326174], Mycoplasma ovis [MG733068] and Rickettsia amblyommatis [KX363842] DNA) controls were included. PCR products were resolved into $2 \%$ agarose gels, using a 100 bp molecular weight marker (nucleic acid markers, Axygen) in $1 \times$ TAE buffer.

\section{Sequencing procedures}

All positive products were purified using the Agencourt AMPure PCR purification kit. Samples were amplified and sequenced using BigDye Terminator v3.1 Cycle Sequencing Kit (Thermo Fisher, Cat.4337455). Sequencing products were purified by BigDye XTerminator (Thermo Fisher, Cat. 4376486) prior to loading on the ABI 3730xL DNA Analyzer at Sequencing Unit of the National Institute of Genomic Medicine, Ministry of Health, Mexico.

Table 1. Primers used for the detection of several bacterial agents.

\begin{tabular}{ccccc}
\hline Pathogen & Gene & Primers & Size (bp) & Reference \\
\hline Bartonella spp. & gltA (Citrate synthase) & BhCS781.p & 379 & Norman et al. (1995) \\
Ehrlichia spp./Anaplasma spp. & 16S rDNA (RNA ribosomal 16S) & BhCS1137.n & EHR01F & Murphy et al. (2017) \\
& & EHR02R & \\
Mycoplasma spp. & 16S rDNA (RNA ribosomal 16S) & HemMycop16S-322s & 1000 & Maggi et al. (2013) \\
& & HemMycop16S-1420as & 806 & de Sousa et al. (2006) \\
Rickettsia spp. & gltA (Citrate synthase) & RpCS.415 & RpCS.1220 & \\
\hline
\end{tabular}




\section{Phylogenetic analysis}

Consensus sequences were constructed using the software Genious, and were aligned with those of reference of each bacterial group deposited in GenBank using Bioedit. Phylogenetic analysis was done using the maximum likelihood method and the best substitution model was selected for each alignment based on the lowest Bayesian Information Criterion (BIC) in Mega 6.0. Sequences generated in this study were deposited in GenBank under accession numbers MH917710- MH917715, and MN294708.

\section{Results}

Activity patterns were observed during day and night. A pack of feral dogs was detected moving across different parts of REPSA (core and buffer zones). Nineteen dogs were captured, 9 males (3 juvenile and 6 adults) and 10 females (4 young and 6 adults) (Figure 1B, Table 1). Thirteen dogs were captured inside the core zones, two in buffers zones and four dogs were captured outside the reserve. All samples were positive for the amplification of the COI gene (internal extraction control). From DNA extraction, we obtained a median concentration of DNA of $173.75 \mathrm{ng} / \mu \mathrm{l}$, with a minimum of $22.90 \mathrm{ng} / \mu \mathrm{l}$ and a maximum of $730.60 \mathrm{ng} / \mu \mathrm{l}$, with a 260/280 coefficient between 1.8 and 2.0. Six dogs (three females and three males) were positive for at least one vector-borne pathogen (Table 2). None of the juvenile dogs tested positive for any pathogen analyzed. Two females and one male were positive for Bartonella DNA; the three sequences exhibited an identity of 99\% (343/344 bp) with sequences of Bartonella vinsonii subsp. berkhoffii detected in dogs and wild carnivores in US and northern Mexico (Accesion numbers CP003124.1 and KT807806.1) (Figure 2A). Two more samples were positive for Ehrlichia DNA; one female and a male, whose sequences were identical to each other and exhibited a identity of 100\% (341/341 bp) with sequences of Ehrlichia canis from dogs, also from the US and South of Mexico (Accesion numbers NR_118741.1 and MH487666.1) (Figure 2B). A single sample tested positive for the presence of a hemotrophic Mycoplasma, and exhibit an identity of $100 \%$ (882/882 bp) with Mycoplasma haemocanis detected in dogs from Chile (Accesion number KY117659.1) (Figure 2C). We did not detect the presence of Anaplasma or Rickettsia in any of the analyzed samples. The presence of coinfections was not detected in any of the blood samples (Table 1). The Maximum Likelihood analysis confirms the identity of the three pathogens, which form monophyletic groups with support values that go between 98-100 with sequences of $B$. vinsonii subsp. berkhoffi, E. canis and $M$. haemocanis, respectively (Figure 2).

Table 2. Positive samples of feral dogs for several tick and flea-borne bacterial, El Pedregal de San Angel Ecological Reserve, Mexico.

\begin{tabular}{|c|c|c|c|c|c|c|}
\hline Code & $\begin{array}{l}\text { Collection } \\
\text { place }\end{array}$ & Sex & Age & Bartonella spp. & Ehrlichia spp. & Mycoplasma spp. \\
\hline 1 & $\mathrm{ZNO}$ & Female & Adult & $(-)$ & $\begin{array}{c}\text { Ehrlichia canis } \\
100 \%(341 / 341) \text { M73226.1 }\end{array}$ & $(-)$ \\
\hline 2 & $\mathrm{ZNO}$ & Male & Adult & $(-)$ & $\begin{array}{c}\text { Ehrlichia canis } \\
100 \%(346 / 346) \text { M73226.1 }\end{array}$ & $(-)$ \\
\hline 3 & ZNSO & Female & Adult & $(-)$ & $(-)$ & $(-)$ \\
\hline 4 & ZNSO & Male & Adult & $\begin{array}{l}\text { Bartonella vinsonii berkhoffi } \\
99 \%(343 / 344) \text { CР } 003124.1\end{array}$ & $(-)$ & $(-)$ \\
\hline 5 & ZNSO & Female & Adult & $\begin{array}{l}\text { Bartonella vinsonii berkhoffi } \\
99 \%(346 / 349) \text { CР } 003124.1\end{array}$ & $(-)$ & $(-)$ \\
\hline 6 & $\mathrm{ZNO}$ & Female & Adult & $(-)$ & $(-)$ & $(-)$ \\
\hline 7 & ZNP & Female & Adult & $\begin{array}{l}\text { Bartonella vinsonii berkhoffii } \\
99 \%(343 / 345) \text { CР } 003124.1\end{array}$ & $(-)$ & $(-)$ \\
\hline 8 & ZNO & Male & Juvenile & $(-)$ & $(-)$ & $(-)$ \\
\hline 9 & DGAE & Female & Adult & $(-)$ & $(-)$ & $(-)$ \\
\hline 10 & ZNO & Female & Juvenile & $(-)$ & $(-)$ & $(-)$ \\
\hline 11 & ZNO & Male & Juvenile & $(-)$ & $(-)$ & $(-)$ \\
\hline 12 & ZNO & Female & Juvenile & $(-)$ & $(-)$ & $(-)$ \\
\hline 13 & $\mathrm{CU}$ & Male & Adult & $(-)$ & $(-)$ & $(-)$ \\
\hline 14 & $\mathrm{CU}$ & Male & Adult & $(-)$ & $(-)$ & $(-)$ \\
\hline 15 & MUAC & Female & Juvenile & $(-)$ & $(-)$ & $(-)$ \\
\hline 16 & $\mathrm{CU}$ & Male & Adult & $(-)$ & $(-)$ & $(-)$ \\
\hline 17 & ZNO & Male & Juvenile & $(-)$ & $(-)$ & $(-)$ \\
\hline 18 & ZNO & Female & Juvenile & $(-)$ & $(-)$ & $(-)$ \\
\hline 19 & $\mathrm{~A} 3 \mathrm{CO}$ & Male & Adult & $(-)$ & $(-)$ & $\begin{array}{c}\text { Mycoplasma haemocanis } \\
100 \%(882 / 882) \text { KY117659.1 }\end{array}$ \\
\hline
\end{tabular}

A3CO: Cantera Oriente; CU: Circuito Universitario; DGAE: Dirección General Administración Escolar; MUAC: Museo Universitario de Arte Contemporáneo; ZNO: Zona Núcleo Oriente; ZNSO: Zona Núcleo Suroriente; ZNP: Zona Núcleo Poniente DNA; (-): Not detected. 


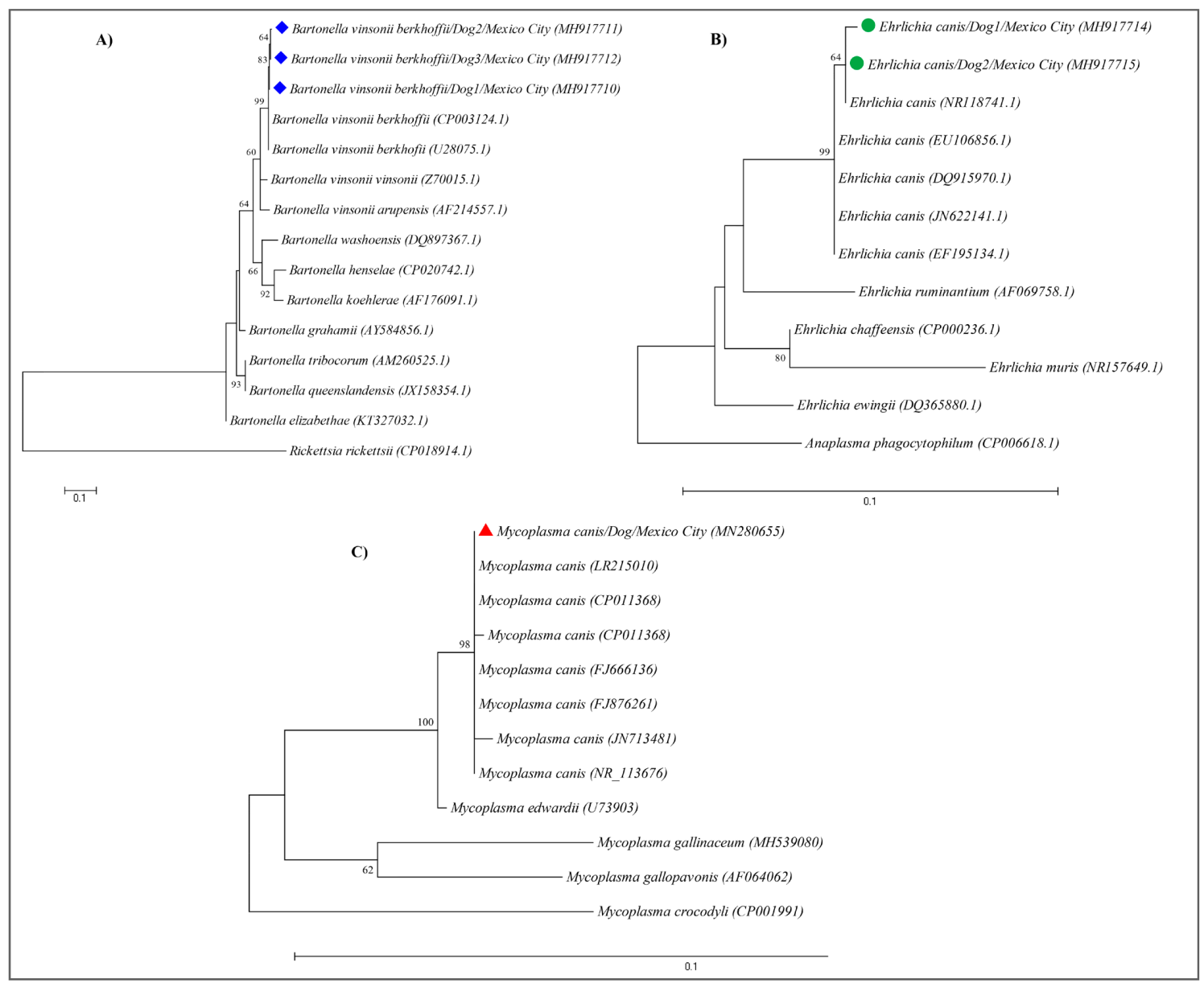

Figure 2. Maximum likelihood phylogenetic tree generated using Tamura three-parameter distance model with partial sequences of: (A) the gltA gene from several members of the genus Bartonella; (B) the 16S rRNA gene from several members of the genus Ehrlichia; (C) the 16S rRNA gene from several members of the genus Mycoplasma. Bootstrap values greater than 50 are indicated at the nodes. Sequences generated in this study are marked with solid forms.

\section{Discussion}

To the best of our knowledge, this is the first study to detect the presence of tick and flea-borne pathogens in feral dogs from Mexico, and it is also the first report of B. vinsonii subsp. berkhoffii and $E$. canis in Mexico City. Besides, our study confirmed, through molecular methods, the presence of $B$. vinsonii subsp. berkhoffic and $M$. haemocanis in Mexican dogs. These results contribute to determining the negative relationship between feral dogs and wild animals of REPSA regarding disease transmission. Ehrlichia canis (the causative agent of canine monocytic ehrlichiosis) is the main rickettsial agent registered in dogs of the Neotropical region, with prevalence ranging between 15 and $70 \%$ (BARRANTES-GONZÁLEZ et al., 2016; MONTENEGRO et al., 2017; ROTONDANO et al., 2017; GEIGER et al., 2018; PAULINO et al., 2018). Clinical signs of an E. canis infection can be variable, depending on the strain, the immune response of the $\mathrm{dog}$, and the presence of concomitant infections with other tick or flea-borne pathogens (SAINZ et al., 2015), however, no clinical signs were observed in the animals captured. In Mexico, it has been reported in several states, mainly in the coastal regions of the Gulf of Mexico and also in the states of the northern border close to the United States of America (RODRÍGUEZ-VIVAS et al., 2005; JIMÉNEZ-COELLO et al., 2009; SOSA-GUTIÉRREZ et al., 2013; PAT-NAH et al., 2015; ALMAZÁN et al., 2016). Ehrlichia canis is not common in humans; however it has been reported causing human disease in Venezuela (PEREZ et al., 2006) and recently in Panama (DAZA et al., 2018).

Bartonella vinsonii subsp. berkhoffii is an emerging pathogen that represents a growing public health problem (ROUX et al., 2000; LANTOS et al., 2014). Initially isolated in 1990, in blood samples of a dog and its owner who had an endocarditis, it has been shown to be a widespread pathogen, which has been detected mainly in the United States and recently in several other countries of South America (KORDICK et al., 1996; FENIMORE et al., 2011; PÉREZ et al., 2011; DINIZ et al., 2013). This is a common pathogen of pets, which is transmitted by contact with infected fleas (MÜLLER et al., 2018). In our study, all positive dogs were captured in the same area of the reserve during a season of the same year. In the North of Mexico, it was reported the presence of this Bartonella species in two wild carnivores, coyotes (Canis latrans) and striped skunks (Mephitis mephitis) (LÓPEZ-PÉREZ et al., 2017), however, its effect on these species is unknown because it 
is the cause of endocarditis in domestic dogs (BILLETER et al., 2012; LÓPEZ-PÉREZ et al., 2017; ROURA et al., 2018).

Mycoplasma haemocanis causes hemolytic anemia in immunocompromised dogs (KAEWMONGKOL et al., 2017). The first record of this pathogen in Mexico was in 1960, and detected in splenectomized dogs (OSORNO \& RISTIC, 1972). Recently it has been demonstrated that the tick Rhipicephalus sanguineus s.l. is capable of transmitting this pathogen (AKTAS \& OZUBEK, 2017). It is possible that the frequency of the three microorganisms is low compared with other studies due to the use of clots instead of whole blood; however it is shown that the sera can be useful for the surveillance of these microorganisms (MYLONAKIS et al., 2009).

Furthermore, because feral dogs have a high vagility and are able to establish close interactions with other groups of wild mammals, the exchange of ectoparasites carrying bacterial agents is highly possible. For this reason, it is essential to determine if any of these agents have been established in wild mammal populations because other animals could be endangered. In REPSA there are records of carnivore species that are classified in risk categories for conservation, for example, the recently rediscovered gray fox (Urocyon cinereoargenteus), and several species of skunks (Spilogale gracilis) and ringtail cats (Bassariscus astutus). Also, because these bacterial species can infect other wild carnivores and some of them have been detected causing disease in humans, it is important to continue with active surveillance in feral dog populations in order to identify the impact of these pathogens in the wild and to establish prevention and protection measures in this group of unattended animals.

\section{Acknowledgements}

The authors would like to thank Saúl Rodríguez for providing the map, Joaquín Montiel for laboratory assistance and Néstor Chavarría for his support during the fieldwork. Especially we thank Alfredo Mendoza Vargas for processing samples for sequencing.

\section{References}

Aktas M, Ozubek S. Molecular survey of haemoplasmas in shelter dogs and associations with Rhipicephalus sanguineus sensu lato. Med Vet Entomol 2017; 31(4): 457-461. http://dx.doi.org/10.1111/mve.12244. PMid:28685834.

Almazán C, González-Álvarez VH, Fernández de Mera IG, Cabezas-Cruz A, Rodríguez-Martínez R, de la Fuente J. Molecular identification and characterization of Anaplasma platys and Ehrlichia canis in dogs in Mexico. Ticks Tick Borne Dis 2016; 7(2): 276-283. http://dx.doi.org/10.1016/j. ttbdis.2015.11.002. PMid:26615872.

Ballados-González GG, Sánchez-Montes S, Romero-Salas D, Colunga Salas P, Gutiérrez-Molina R, León-Paniagua L, et al. Detection of pathogenic Leptospira species associated with phyllostomid bats (Mammalia: Chiroptera) from Veracruz, Mexico. Transbound Emerg Dis 2018; 65(3): 773-781. http://dx.doi.org/10.1111/tbed.12802. PMid:29318786.

Barnes A, Bell SC, Isherwood DR, Bennett M, Carter SD. Evidence of Bartonella henselae infection in cats and dogs in the United Kingdom. Vet Rec 2000; 147(24): 673-677. PMid:11132671.
Barrantes-González AV, Jiménez-Rocha AE, Romero-Zuñiga JJ, Dolz G. Serology, molecular detection and risk factors of Ehrlichia canis infection in dogs in Costa Rica. Ticks Tick Borne Dis 2016; 7(6): 1245-1251. http:// dx.doi.org/10.1016/j.ttbdis.2016.07.006. PMid:27440400.

Billeter SA, Breitschwerdt EB, Levy MG. Invasion of canine erythrocytes by Bartonella vinsonii subsp. berkhoffii. Vet Microbiol2012; 156(1-2): 213216. http://dx.doi.org/10.1016/j.vetmic.2011.10.020. PMid:22071179.

Castillo-Arguero S, Martinez-Orea Y, Romero-Romero M, GuadarramaChavez P, Nunez-Castillo O, Sanchez-Gallen I, et al. La Reserva Ecológica del Pedregal de San Ángel: Aspectos Florísticos y Ecológicos. Mexico City: Universidad Nacional Autonoma de Mexico; 2007.

Chen J, Xu MJ, Zhou DH, Song HQ, Wang CR, Zhu XQ. Canine and feline parasitic zoonoses in China. Parasit Vectors 2012; 5(1): 152. http:// dx.doi.org/10.1186/1756-3305-5-152. PMid:22839365.

Cruz-Reyes A. Fauna feral, fauna nociva y zoonosis. In: Lot A, CanoSantana Z. Biodiversidad del ecosistema del Pedregal de San Ángel. Ciudad de México: Universidad Nacional Autónoma de México; 2009. p. 453-461.

Daza C, Osorio J, Santamaria A, Suárez J, Hurtado A, Bermúdez S. Caracterización del primer caso de infección humana por Ehrlichia canis en Panamá. Rev Med Panama 2018; 38(3): 63-68.

de Sousa R, Barata C, Vitorino L, Santos-Silva M, Carrapato C, Torgal J, et al. Rickettsia sibirica isolation from a patient and detection in ticks, Portugal. Emerg Infect Dis 2006; 12(7): 1103-1108. http://dx.doi. org/10.3201/eid1207.051494. PMid:16836827.

Deplazes P, van Knapen F, Schweiger A, Overgaauw PA. Role of pet dogs and cats in the transmission of helminthic zoonoses in Europe, with a focus on echinococcosis and toxocarosis. Vet Parasitol 2011; 182(1): 4153. http://dx.doi.org/10.1016/j.vetpar.2011.07.014. PMid:21813243.

Diniz PP, Morton BA, Tngrian M, Kachani M, Barrón EA, Gavidia $\mathrm{CM}$, et al. Infection of domestic dogs in Peru by zoonotic Bartonella species: a cross-sectional prevalence study of 219 asymptomatic dogs. PLoS Negl Trop Dis 2013; 7(9): e2393. http://dx.doi.org/10.1371/journal. pntd.0002393. PMid:24040427.

Doherty T, Glen A, Nimmo D, Ritchie E, Dickman C. Invasive predators and global biodiversity loss. Proc Natl Acad Sci USA 2016; 113(40): 11261 11265. http://dx.doi.org/10.1073/pnas.1602480113. PMid:27638204.

Estañol-Tecuatl F, Cano-Santana Z. Recovery of basalt substrate for xeric scrub restoration in a Lava Field in Mexico City. Ecol Res 2017; 35(1): 41-51. http://dx.doi.org/10.3368/er.35.1.41.

Fang F, Li J, Huang T, Guillot J, Huang W. Zoonotic helminths parasites in the digestive tract of feral dogs and cats in Guangxi, China. BMC Vet Res 2015; 11(1): 211. http://dx.doi.org/10.1186/s12917-015-0521-7. PMid:26276147.

Fenimore A, Varanat M, Maggi R, Schultheiss P, Breitschwerdt E, Lappin M. Bartonella spp. DNA in cardiac tissues from dogs in Colorado and Wyoming. J Vet Intern Med 2011; 25(3): 613-616. http://dx.doi. org/10.1111/j.1939-1676.2011.0722.x. PMid:21539606.

Geiger J, Morton B, Vasconcelos E, Tngrian M, Kachani M, Barrón E, et al. Molecular characterization of tandem repeat protein 36 gene of Ehrlichia canis detected in naturally infected dogs from Peru. Am J Trop Med Hyg 2018; 99(2): 297-302. http://dx.doi.org/10.4269/ ajtmh.17-0776. PMid:29943707.

Hughes J, Macdonald D. A review of the interactions between freeroaming domestic dogs and wildlife. Biol Conserv 2013; 157: 341-351. http://dx.doi.org/10.1016/j.biocon.2012.07.005. 
Jiménez-Coello M, Pérez-Osorio C, Vado-Solís I, Rodríguez-Buenfil J, Ortega-Pacheco A. Serological survey of Ehrlichia canis in stray dogs from Yucatan, Mexico, using two different diagnostic tests. Vector Borne Zoonotic Dis 2009; 9(2): 209-212. http://dx.doi.org/10.1089/ vbz.2008.0039. PMid:18945189.

Kaewmongkol G, Lukkana N, Yangtara S, Kaewmongkol S, Thengchaisri N, Sirinarumitr T, et al. Association of Ehrlichia canis, Hemotropic Mycoplasma spp. and Anaplasma platys and severe anemia in dogs in Thailand. Vet Microbiol 2017; 201: 195-200. http://dx.doi.org/10.1016/j. vetmic.2017.01.022. PMid:28284610.

Kordick D, Swaminathan B, Greene C, Wilson K, Whitney A, O'Connor $S$, et al. Bartonella vinsonii subsp. berkhoffii subsp. nov., isolated from dogs; Bartonella vinsonii subsp. vinsonii; and emended description of Bartonella vinsonii. Int J Syst Bacteriol 1996; 46(3): 704-709. http:// dx.doi.org/10.1099/00207713-46-3-704. PMid:8782679.

Lantos P, Maggi R, Ferguson B, Varkey J, Park L, Breitschwerdt E, et al. Detection of Bartonella species in the blood of veterinarians and veterinary technicians: a newly recognized occupational hazard? Vector Borne Zoonotic Dis 2014; 14(8): 563-570. http://dx.doi.org/10.1089/vbz.2013.1512. PMid:25072986.

López-Pérez A, Osikowicz L, Bai Y, Montenieri J, Rubio A, Moreno $\mathrm{K}$, et al. Prevalence and phylogenetic analysis of Bartonella species of wild carnivores and their fleas in northwestern Mexico. EcoHealth 2017; 14(1): 116-129. http://dx.doi.org/10.1007/s10393-017-1216-2. PMid:28197898.

Maggi RG, Mascarelli PE, Havenga LN, Naidoo V, Breitschwerdt EB. Co-infection with Anaplasma platys, Bartonella henselae and Candidatus Mycoplasma haematoparvum in a veterinarian. Parasit Vectors 2013; 6(1): 103. http://dx.doi.org/10.1186/1756-3305-6-103. PMid:23587235.

Marsico TD, Wallace LE, Ervin GN, Brooks CP, McClure JE, Welch ME. Geographic patterns of genetic diversity fromthe native range of Cactoblastis cactorum (Berg) support the documented history of invasion and multiple introductions for invasive populations. Biol Invasions 2010; 2: 654-671. http://dx.doi.org/10.1007/s11250-018-1648-x.

Martínez-Orea Y, Castillo-Argüero S, Hernández-Apolinar M, GuadarramaChávez M, Orozco-Segovia A. Seed rain after a fire in a xerophytic shrubland. Rev Mex Biodivers 2012; 83(2): 447-457.

Montenegro V, Bonilla M, Kaminsky D, Romero-Zúńiga J, Siebert S, Krämer F. Serological detection of antibodies to Anaplasma spp., Borrelia burgdorferi sensu lato and Ehrlichia canis and of Dirofilaria immitis antigen in dogs from Costa Rica. Vet Parasitol 2017; 236: 97-107. http://dx.doi. org/10.1016/j.vetpar.2017.02.009. PMid:28288773.

Müller A, Soto F, Sepúlveda M, Bittencourt P, Benevenute JL, Ikeda P, et al. Bartonella vinsonii subsp. berkhoffii and B. henselae in dogs. Epidemiol Infect. 2018; 146(9): 1202-1204. https://doi: 10.1017/S0950268818001127.

Murphy D, Lee X, Larson S, Johnson D, Loo T, Paskewitz S. Prevalence and distribution of human and tick infections with the Ehrlichia muris-Like Agent and Anaplasma phagocytophilum in Wisconsin, 2009-2015. Vector Borne Zoonotic Dis 2017; 17(4): 229-236. http://dx.doi.org/10.1089/ vbz.2016.2055. PMid:28055326.

Mylonakis ME, Siarkou VI, Leontides L, Bourtzi-Hatzopoulou E, Kontos VI, Koutinas A. F. Evaluation of a serum-based PCR assay for the diagnosis of canine monocytic ehrlichiosis. Vet Microbiol 2009; 138(3-4): 390-393. http://dx.doi.org/10.1016/j.vetmic.2009.04.015. PMid:19419823.

Norman A, Regnery R, Jameson P, Greene C, Krause D. Differentiation of Bartonella-like isolates at the species level by PCR-restriction fragment length polymorphism in the citrate synthase gene. J Clin Microbiol 1995 33(7): 1797-1803. PMid:7545181.

Osorno B, Ristic M. Aislamiento e identificación de Haemobartonella canis en México. Rev Mex Cienc Pecu 1972; 2: 23-24.

Pat-Nah H, Rodriguez-Vivas R, Bolio-Gonzalez M, Villegas-Perez S, Reyes-Novelo E. Molecular diagnosis of Ehrlichia canis in dogs and ticks Rhipicephalus sanguineus (Acari: Ixodidae) in Yucatan, Mexico. J Med Entomol 2015; 52(1): 101-104. http://dx.doi.org/10.1093/jme/ tju010. PMid:26336286.

Paul M, Majumder S, Bhadra A. Grandmotherly care: a case study in Indian free-ranging dogs. J Ethol 2014; 32(2): 75-82. http://dx.doi. org/10.1007/s10164-014-0396-2.

Paulino P, Pires M, da Silva C, Peckle M, da Costa R, Vitari G, et al. Epidemiology of Ehrlichia canis in healthy dogs from the southeastern region of the state of Rio de Janeiro, Brazil. Prev Vet Med 2018; 159: 135-142. http://dx.doi.org/10.1016/j.prevetmed.2018.09.012. PMid:30314776.

Pérez C, Maggi R, Diniz P, Breitschwerdt E. Molecular and serological diagnosis of Bartonella infection in $61 \mathrm{dogs}$ from the United States. $J$ Vet Intern Med 2011; 25(4): 805-810. http://dx.doi.org/10.1111/j.19391676.2011.0736.x. PMid:21615498.

Perez M, Bodor M, Zhang C, Xiong Q, Rikihisa Y. Human infection with Ehrlichia canis accompanied by clinical signs in Venezuela. Ann N Y Acad Sci 2006; 1078(1): 110-117. http://dx.doi.org/10.1196/ annals.1374.016. PMid:17114689.

Plumb D. Veterinary drug handbook. 7th ed. Ames: PharmaVet Inc; 2011.

Rodriguez-Vivas R, Albornoz R, Bolio G. Ehrlichia canis in dogs in Yucatan, Mexico: seroprevalence, prevalence of infection and associated factors. Vet Parasitol 2005; 127(1): 75-79. http://dx.doi.org/10.1016/j. vetpar.2004.08.022. PMid:15619376.

Rotondano T, Krawczak F, Barbosa W, Moraes-Filho J, Bastos F, Labruna M, et al. Ehrlichia canis and Rickettsia spp. in dogs from urban areas in Paraiba state, northeastern Brazil. Rev Bras Parasitol Vet 2017; 26(2): 211 215. http://dx.doi.org/10.1590/s1984-29612017030. PMid:28658415.

Roura X, Santamarina G, Tabar M, Francino O, Altet L. Polymerase chain reaction detection of Bartonella spp. in dogs from Spain with blood culture-negative infectious endocarditis. J Vet Cardiol 2018; 20(4): 267 275. http://dx.doi.org/10.1016/j.jvc.2018.04.006. PMid:29807750.

Roux V, Eykyn S, Wyllie S, Raoult D. Bartonella vinsonii subsp. berkhoffi as an agent of afebrile blood culture-negative endocarditis in a human. $J$ Clin Microbiol 2000; 38(4): 1698-1700. PMid:10747175.

Sainz A, Roura X, Miró G, Estrada-Peña A, Kohn B, Harrus S, et al. Guideline for veterinary practitioners on canine ehrlichiosis and anaplasmosis in Europe. Parasit Vectors 2015; 8(1): 75. http://dx.doi. org/10.1186/s13071-015-0649-0. PMid:25649069.

Sosa-Gutierrez C, Quintero Martinez M, Gaxiola Camacho S, Cota Guajardo S, Esteve-Gassent M, Gordillo-Pérez M. Frequency and clinical epidemiology of canine monocytic ehrlichiosis in dogs infested with ticks from Sinaloa, Mexico. J Vet Med 2013; 2013: 797019. http://dx.doi. org/10.1155/2013/797019. PMid:26464910.

Suzán G, Ceballos G. The role of feral mammals on wildlife infectious disease prevalence in two nature reserves within Mexico City limits. $J$ Zoo Wildl Med 2005; 36(3): 479-484. http://dx.doi.org/10.1638/04078.1. PMid:17312768. 